\title{
The effect of marine algae in the ration of high-yielding dairy cows during transition on metabolic parameters in serum and follicular fluid around parturition
}

\author{
M. Hostens, ${ }^{* 1}$ V. Fievez,† B. Vlaeminck,† J. Buyse,‡ J. Leroy,§ S. Piepers, ${ }^{\star}$ S. De Vliegher, ${ }^{\star}$ and G. Opsomer ${ }^{\star}$ \\ *Department of Reproduction, Obstetrics and Herd Health, Faculty of Veterinary Medicine, Ghent University, Salisburylaan 133, 9820 Merelbeke, \\ Belgium \\ †Laboratory for Animal Nutrition and Animal Product Quality, Faculty of Bioscience Engineering, Ghent University, Proefhoevestraat 10, \\ 9090 Melle, Belgium \\ ¥Laboratory for Physiology of Domestic Animals, Department of Animal Production, Catholic University of Leuven, Kasteelpark Arenberg 30, \\ 3001 Heverlee, Belgium \\ $\S$ Laboratory for Veterinary Physiology, Department of Veterinary Sciences, Faculty of Biomedical, Pharmaceutical and Veterinary Sciences, \\ University of Antwerp, Universiteitsplein 1, 2610 Wilrijk, Belgium
}

\section{ABSTRACT}

Sixteen Holstein cows were assigned to 2 groups to evaluate the caloric and metabolic effect of feeding marine algae (ALG) from $3 \mathrm{wk}$ prepartum until $12 \mathrm{wk}$ postpartum. Milk production characteristics and the profiles of hormones and metabolites in the serum were monitored from -7 to $46 \mathrm{~d}$ in milk (DIM) and in follicular fluid (FF) from 14 to 46 DIM. All cows received a corn- and grass silage-based partially mixed ration supplemented with concentrate and protein supplement. In the diet of the ALG group, $2 \mathrm{~kg}$ of the concentrate was replaced by a concentrate containing ALG ( $44 \mathrm{~g} / \mathrm{d}$ of docosahexaenoic acid). Diets were isocaloric (net energy basis) and equal in intestinal digestible protein. The ALG diet increased milk yield (41.2 vs. $38.2 \mathrm{~kg} / \mathrm{d}$ ) and decreased milk fat yield (1.181 vs. 1.493 $\mathrm{kg} / \mathrm{d}$ ) and milk fat content (31.6 vs. $40.7 \mathrm{~g} / \mathrm{kg}$ ). Protein yield (1.336 vs. $1.301 \mathrm{~kg} / \mathrm{d}$ ) was not affected but a tendency toward decreased milk protein content (32.8 vs. $34.7 \mathrm{~g} / \mathrm{kg}$ ) was observed. Marine algae supplementation increased the $\beta$-hydroxybutyric acid (BHBA) concentration in FF of the ALG cows compared with that in the controls $(0.992$ vs. $0.718 \mathrm{mmol} / \mathrm{L})$. The total protein concentration in FF was decreased in ALG (62.9 vs. $67.6 \mathrm{~g} / \mathrm{L}$ ). Plasma and serum metabolites did not significantly differ between treatments except for a tendency toward a lower concentration of urea in the serum of the control compared with ALG (4.69 vs. 5.13 $\mathrm{mmol} / \mathrm{L}$ ). Based on metabolizable energy calculations, a daily energy-sparing effect of $3.48 \mathrm{Mcal}$ was obtained due to milk fat depression (MFD). The concomitant increase in milk yield suggests that at least part of

Received October 5, 2010

Accepted May 27, 2011.

${ }^{1}$ Corresponding author: Miel.Hostens@UGent.be this spared energy is used to stimulate milk production. Theoretically, 3.48 Mcal of ME could lead to an increase in milk yield of $7.43 \mathrm{~kg} / \mathrm{d}$, which is higher than the observed $3 \mathrm{~kg} / \mathrm{d}$. However, when evaluating nutrient requirements during MFD in early lactation, we calculated that increased milk production is caused by a propionate-saving effect of $2.71 \mathrm{~mol}$ in the udder when milk fat is depressed. Concurrent increased BHBA concentrations in FF in the ALG group cannot be attributed to a worsened energy status of the animals because all other indicators contradict any change in energy balance, indicating that BHBA might not be an appropriate metabolic parameter to estimate the energy balance in early lactating dairy cows during MFD. Key words: dairy cow, marine algae, milk fat depression, negative energy balance

\section{INTRODUCTION}

Milk production of high-yielding dairy cows has increased over the last 40 years while fertility has decreased (Lucy, 2001). In Belgium, milk production in dairy cattle has increased from $6,000 \mathrm{~kg}$ of milk per lactation in 1991 to $9,000 \mathrm{~kg}$ of milk per lactation in 2007; simultaneously, the calving interval has increased by 28 d (Flemish Cattle Breeding Association, 2008). This decrease in fertility has been shown to be associated with the negative energy balance (NEBAL) that highyielding dairy cows encounter during the transition period (van Knegsel et al., 2005; Dobson et al., 2007; Grummer, 2007). In this period, substrate availability for gluconeogenesis is limiting due to both decreased DMI and the adaptation of the rumen. A simultaneous increasing demand for milk lactose synthesis pushes the cow's metabolism to switch to depletion of body reserves; that is, NEBAL (Drackley et al., 2005). Leroy et al. (2004) showed a significant correlation between the concentrations of biochemical indicators of NEBAL 
(BHBA, glucose, NEFA) in the serum and follicular fluid (FF) of high-yielding dairy cows early postpartum. Later, the same authors (Leroy et al., 2005, 2006) mimicked the follicular environment encountered in vivo in an in vitro maturation model and observed a marked deleterious effect on the developmental capacity of bovine oocytes. These findings substantiate the suggestions made by others (O'Callaghan and Boland, 1999; Horan et al., 2005) that the decline in fertility is mainly caused by inferior oocyte and embryo quality. Britt (1992) suggested a carryover effect of metabolic conditions in times of energy deficit early postpartum on preovulatory follicles 2 to 3 mo later. Therefore, the effect of the FF, the environment in which the oocyte matures before ovulation, cannot be neglected when evaluating the effect of the NEBAL in high-yielding dairy cows. This explains why many efforts have been made to alleviate the NEBAL of high-yielding dairy cows early postpartum and consequently improve the concentration of biochemical markers in both serum and FF of high-yielding dairy cows to ameliorate reproductive capacity. Additionally, the fatty acid composition of the FF might be of importance, with C16:0 and C18:0 having a detrimental effect on oocyte maturation (Leroy et al., 2005).

One of the strategies to diminish NEBAL postpartum is the induction of milk fat depression (MFD) to substantially decrease energy output, because the production of fat comes with the greatest demand for energy (Jensen, 2002). Daily supplementation of $19 \mathrm{~g}$ of the trans-10,cis-12 isomer of conjugated linoleic acid (CLA) induced MFD in periparturient cows, which was associated with a significant decrease in NEFA and an increase in glucose concentrations, indicating an improved energetic status of the supplemented cows (Odens et al., 2007).

When fed to dairy cows in established lactation, docosahexaenoic acid (DHA)-enriched marine algae (Schizochytrium spp.) induce MFD (Boeckaert et al., 2008). To our knowledge, no experiments have been done in which long-chain n-3 fatty acids (FA) such as DHA were examined to induce a MFD in early lactation with concomitant registration of NEBAL indicators. Our objectives were to induce MFD in early lactation by feeding DHA and to determine the dietary effect on milk production, milk components, and metabolic status as measured in the serum and FF early postpartum in high-yielding dairy cows.

\section{MATERIALS AND METHODS}

\section{Experimental Design}

All procedures and protocols were approved by the Ethical Committee of the Faculty of Veterinary Medi- cine (Ghent University). Sixteen healthy primiparous $(\mathrm{n}=6 ;$ PRIM $)$ and multiparous $(\mathrm{n}=10 ; \mathbf{M U L T})$ Holstein cows participated in this study. The study was conducted at the experimental research farm of Ghent University (Biocentrum Agrivet, Melle, Belgium). On this farm, the average 305-d milk yield per cow was $9,934 \mathrm{~kg}$ of milk $(38.6 \mathrm{~g} / \mathrm{kg}$ of fat and $34.7 \mathrm{~g} / \mathrm{kg}$ of protein). During the experimental period (August 2007 through March 2008), all cows were housed in a loose stable with cubicles. Cows were milked by means of an automated voluntary milking system (DeLaval, Tumba, Sweden).

The cows were blocked for parity, expected calving date, estimated milk and milk fat production, and genetic origin (cows with the same ancestors were assigned to different treatment groups) and assigned to 2 different treatment groups in a randomized complete block design. The MULT cows were dried off in their previous lactation to achieve an average dry period length of $55 \mathrm{~d}$, during which they were offered wheat straw (ad libitum), $7 \mathrm{~kg}$ DM of corn silage, and $1.4 \mathrm{~kg}$ DM of soybean meal (Aveve, Merksem, Belgium), 25 $\mathrm{g}$ of magnesium oxide (Nutreco, Ghent, Belgium), and $200 \mathrm{~g} / \mathrm{d}$ of a dry period mineral mixture (Runergeen, P5, Nutreco) until d 20 ( \pm 3.5 SD) before the calving date. For these last $20 \mathrm{~d}$, the animals were transferred to the lactating group to adapt to the partially mixed ration (PMR) offered to the cows after calving. Similarly, the PRIM cows were transferred to the lactating group $19 \mathrm{~d}( \pm 3 \mathrm{SD})$ before their actual calving date. The pen-fed PMR offered to all close-up and lactating cows consisted of high quality roughages, corn and grass silage, soybean meal, corn cob mix, sugar beet pulp, hay grass, and minerals (531, 241, 100, 57, 45, 22, and $4 \mathrm{~g} / \mathrm{kg}$, DM basis, respectively) besides the specific concentrates to which they were assigned.

\section{Dietary Treatments}

In addition to the PMR, the control group (CON) was offered $2 \mathrm{~kg}$ of concentrate (Glucolac 21, Aveve Group, Merksem, Belgium; Table 1) from $14 \mathrm{~d}$ before parturition. This concentrate allowed for equal fatand protein-corrected milk (FPCM) production from the energy (based on $\mathrm{NE}_{\mathrm{L}}$; Van Es, 1978) and protein (based on the Dutch DVE system; Tamminga et al., 1994) content. After parturition, the amount of concentrate increased over $20 \mathrm{~d}$ to a maximum of $3 \mathrm{~kg}$ for PRIM cows and $6 \mathrm{~kg}$ for MULT cows. From parturition, a protein supplement (Aminolac 38 Extra, Aveve Group; Table 1) was offered at a constant amount of 2 $\mathrm{kg}$ to all animals until the end of the trial in addition to the concentrate. The concentrate and protein supplement were individually offered via computerized feeders (DeLaval feeding station standard, DeLaval). 
Table 1. Ingredient composition of concentrates used in the experiment

\begin{tabular}{|c|c|c|c|}
\hline \multirow[b]{2}{*}{ Item } & \multicolumn{3}{|c|}{ Concentrate $^{1}$} \\
\hline & ALG & Aminolac & Glucolac \\
\hline \multicolumn{4}{|l|}{ Chemical composition, $\mathrm{g} / \mathrm{kg}$ of DM } \\
\hline DM & 890.0 & 890.0 & 890.0 \\
\hline Crude ash & 46.0 & 110.0 & 70.0 \\
\hline $\mathrm{CP}$ & 198.0 & 390.5 & 217.5 \\
\hline Crude fat & 82.0 & 42.0 & 42.5 \\
\hline $\mathrm{VEM}_{2}^{2} / \mathrm{kg}$ of DM & $1,148.00$ & 930.00 & 960.00 \\
\hline $\mathrm{DVE}^{3}$ & 139.00 & 200.00 & 115.00 \\
\hline \multicolumn{4}{|l|}{ Ingredient, $\mathrm{g} / \mathrm{kg}$ of product } \\
\hline Rapeseed meal & 96.0 & 150.0 & 300.0 \\
\hline Rapeseed hulls & - & 150.0 & - \\
\hline Soybean hulls & - & - & 210.0 \\
\hline Corn middlings & - & - & 110.0 \\
\hline Corn gluten feed & 96.0 & - & - \\
\hline Wheat middlings & - & - & 110.0 \\
\hline Beet vinasse & - & 20.0 & 90.0 \\
\hline Wheat & 192.0 & - & 80.0 \\
\hline Toasted soybean expeller & 55.0 & 600.0 & 61.0 \\
\hline Citrus pulp & - & - & 30.0 \\
\hline Formaldehyde-treated soybean meal & 53.0 & - & - \\
\hline Sunflower expeller & - & 40.0 & - \\
\hline Palmseed hulls & - & - & 8.0 \\
\hline Palm oil & - & 2.0 & 4.0 \\
\hline Beet pulp & 288.0 & - & - \\
\hline Beet molasses & 67.0 & - & - \\
\hline Alfalfa pellets & & - & - \\
\hline DHA Gold & 110.0 & - & - \\
\hline Other components & 43.0 & 38.0 & - \\
\hline
\end{tabular}

The cows in the marine algae group (ALG) were fed according to the same protocol as the CON. The algae concentrate included DHA-enriched marine algae (Schizochytrium spp.) at a final concentration of 110 $\mathrm{g} / \mathrm{kg}$ DHA-Gold (Martek DHA Gold, Martek Biosciences Corp., Colombia, MD; Table 1). The amount of marine algae concentrate supplied to the cows of the treatment group remained at $2 \mathrm{~kg}$ (224 g of DHA-Gold, $44 \mathrm{~g}$ of DHA) throughout the entire postpartum period (46 d), whereas the prepartum supply was fixed at 1.8 $\mathrm{kg}$ of DHA concentrate (202 g of DHA-Gold) from 20 $\mathrm{d}$ before parturition. The pre- and postpartum supply of the concentrate (Glucolac 21) and protein supplement (Aminolac 38 Extra) were calculated to provide the same energy (based on $\mathrm{NE}_{\mathrm{L}}$; Van Es, 1978) and protein (based on the Dutch DVE system; Tamminga et al., 1994) supply in the total ration as calculated for the CON. For PRIM and MULT cows, respectively, this was calculated to be $0.81 \mathrm{~kg}$ of Glucolac $21,1.17 \mathrm{~kg}$ of Aminolac 38 Extra, and $2 \mathrm{~kg}$ of marine algae, and 2.81 $\mathrm{kg}$ of Glucolac 21, $1.17 \mathrm{~kg}$ of Aminolac 38 Extra, and 2 $\mathrm{kg}$ of marine algae at $21 \mathrm{~d}$.

\section{Body Condition Scoring}

Body condition scores were recorded weekly by the same person using a score on a 1 to 5 scale, with 0.25-point increments (Edmonson et al., 1989) from the week before the expected calving day until wk 12 after parturition.

\section{Sampling}

The planned day of prepartum blood samples on d 10 before parturition $(\mathrm{d}-10)$ differed from the actual collection day $(\mathrm{d}-13 \pm 4.5 \mathrm{SD})$ because of unpredictable differences between the expected and actual calving dates of the cows. Postpartum samples were taken on d $0,11,14,20,26,33,40$, and 46 following parturition. Blood samples were taken from the coccygeal vein into 3 unheparinized, silicone-coated tubes (Venoject, Autosep, Gel + Clotting Activator, Terumo Europe N.V., Leuven, Belgium), 2 tubes with EDTA (Venoject, Autosep, Terumo Europe N.V.), and 1 tube with sodium fluoride (glycolytic inhibitor; Venoject, Autosep, 
Terumo Europe N.V.). Follicular fluid was collected on d $14,20,26,33,40$, and 46 by means of transvaginal aspiration following the protocol described by Leroy et al. (2004). The follicles with a diameter greater than $8 \mathrm{~mm}$ were aspirated to minimize size effects on follicular composition (Leroy et al., 2004). Attention was paid to prevent blood contamination. Follicular fluid samples with obvious blood contamination were omitted from further processing. All blood and follicular samples were transported to the laboratory at $4^{\circ} \mathrm{C}$. Within $1.5 \mathrm{~h}$ after collection, samples were centrifuged $(20 \mathrm{~min}$ at $1,500 \times g)$. Serum and plasma samples were stored at $-20^{\circ} \mathrm{C}$ and $\mathrm{FF}$ samples at $-80^{\circ} \mathrm{C}$ until biochemical analysis.

Milk samples were taken weekly starting on d 5 after parturition for 12 consecutive weeks. After proportionally pooling all milk samples from $1 \mathrm{~d}$ according to milk yield, subsamples were mixed with a preservative $(8 \mathrm{mg}$ of bronopol and $0.3 \mathrm{mg}$ of natamycine) and sent refrigerated $\left(4^{\circ} \mathrm{C}\right)$ to the Milk Control Centre of Flanders (Melk Controle Centrum Vlaanderen, Lier, Belgium) for milk fat and protein analysis. A second milk sample was stored frozen before milk fat extraction for milk fatty acid determination.

\section{Chemical Analyses}

Analysis of chemical composition of concentrates consisted of determination of DM (European Economic Community 1971a), crude ash by incineration $\left(550^{\circ} \mathrm{C}\right.$, 2 h; European Economic Community 1971b), CP according to the Kjeldahl method (European Community 1993), and crude fat with the Soxhlet method according to ISO 6492-1999 (ISO, 1999).

The serum and FF analysis for albumin, aspartate aminotransferase (AST), BHBA, glucose, $\gamma$-glutamyltransferase (GGT), L-lactate, NEFA, urea, total cholesterol, and total protein were carried out by means of an automated colorimetrical analyzer (Konelab 20 XTi Clinical chemistry analyzer, Thermo Electron Corp., Vantaa, Finland) at The Flemish Veterinary Health Service (Dierengezondheidszorg-Vlaanderen, Torhout, Belgium). Commercial kits from Konelab/ DPC T Series (Thermo Electron Corp.) were used for the determination of AST (cat no. 981363/981771) and urea (cat no. 981818/981820), from Konelab (Thermo Electron Corp.) for albumin (cat no. 981358/981767), glucose (cat no. 981304/981779), GGT (cat no. 981377/981778), NEFA (cat no. FA 115), total cholesterol (cat no. 981812/981813), and total protein (cat no. 981387/981785), and from Randox Laboratories Ltd. (Antrim, United Kingdom) for BHBA (Ranbut, cat no. RB1007/RB1008) and L-lactate (cat no. LC 2389). Radioimmunoassay was performed for the determination of plasma insulin according to Istasse et al. (1990) and for the determination of growth hormone $(\mathbf{G H})$ and IGF-I as described by Renaville et al. (1993). All blood analyses were carried out on serum derived from the unheparinized, silicone-coated tubes except those for insulin, GH, IGF-I, and glucose. The insulin, GH, and IGF-I analyses were performed on plasma derived from EDTA tubes, whereas the glucose assay was performed on plasma derived from the sodium fluoride tubes.

Estrogen (E2) and progesterone (P4) concentrations of $\mathrm{FF}$ samples was determined via radioimmunoassay using commercial kits from Diagnostic Systems Laboratories Inc. (Los Angeles, CA; Estradiol Double Antibody RIA kit and Progesterone Double Antibody RIA kit). Follicles determined as being atretic according to the classification described by Hendriksen et al. (2003) were omitted from further analysis.

Milk fat and protein contents were analyzed by midinfrared spectrophotometry (MilkoScan 4000/FT6000, Foss, Amersfoort, the Netherlands) in the milk subsample containing the preservative. The FPCM was calculated as $[(0.337+0.116 \times$ milk fat $\%+0.06$ $\times$ milk protein $\%) \times \mathrm{kg}$ of milk] $(\mathrm{CVB}, 2007)$. Milk fat was extracted as described by Vlaeminck et al. (2005), and fatty acid methyl esters were prepared by base-catalyzed transmethylation according to Christie (1982), with modifications by Chouinard et al. (1999). Fatty acid methyl esters (FAME) were quantified using a gas chromatograph (HP 6890, Hewlett-Packard, Brussels, Belgium) equipped with a CP-Sil88 column for FAME $(100 \mathrm{~m} \times 250 \mu \mathrm{m} \times 0.2 \mu \mathrm{m}$, Chrompack, Middelburg, the Netherlands). Conditions for FAME analysis in milk fat were as described by Vlaeminck et al. (2005). Fatty acid methyl esters were identified using external standards (S37, Supelco, Poole, Dorset, UK; CLA cis-9,trans-11, CLA trans-10, cis-12, odd- and branched-chain fatty acids, Larodan Fine Chemicals AB, Malmö, Sweden) and quantified using the internal standard. Milk fatty acids were grouped according to their chain length into short-chain fatty acids [SCFA $=\Sigma(\mathrm{C} 4: 0, \mathrm{C} 5: 0, \mathrm{C} 6: 0, \mathrm{C} 7: 0, \mathrm{C} 8: 0, \mathrm{C} 9: 0)]$, medium-chain fatty acids $[$ MCFA $=\Sigma(\mathrm{C} 10: 0, \mathrm{C} 10: 1, \mathrm{C} 11: 0, \mathrm{C} 12: 0$, $\mathrm{C} 12: 1, \mathrm{C} 13: 0, \mathrm{C} 14: 0, \mathrm{C} 14: 1, \mathrm{C} 15: 0$, iso C13:0, anteiso $\mathrm{C} 13: 0$, iso $\mathrm{C} 14: 0$, iso $\mathrm{C} 15: 0$, anteiso $\mathrm{C} 15: 0)]$, and longchain fatty acids [LCFA $=\Sigma(\mathrm{C} 17: 0, \mathrm{C} 17: 1, \mathrm{C} 18: 0$, trans-4 C18:1, trans-5 C18:1, trans-6 C18:1, trans-9 C18:1, trans-10 C18:1, trans-11 C18:1, trans-12 C18:1, cis-9 18:1, cis-11 C18:1, cis-12 C18:1, cis-13 C18:1, cis-14 18:1, cis-15 C18:1, trans-11,cis-15 C18:2, C18:2, C20:0, C18:2 n-6, C18:3 n-3, cis-9,trans-11 C18:2, trans-9,cis-11 C18:2, trans-10, cis-12 C18:2, C22:6 n-3)], and according to the level of saturation into saturated fatty acids [SFA $=\Sigma(\mathrm{C} 4: 0, \mathrm{C} 5: 0, \mathrm{C} 6: 0, \mathrm{C} 7: 0, \mathrm{C} 8: 0$, C9:0, C10:0, C11:0, C12:0, C13:0, C14:0, C15:0, C16:0, 
$\mathrm{C} 17: 0, \mathrm{C} 18: 0, \mathrm{C} 20: 0$, iso C13:0, iso C14:0, iso C15:0, anteiso $\mathrm{C} 15: 0$, iso $\mathrm{C} 16: 0$, iso $\mathrm{C} 17: 0$, iso $\mathrm{C} 18: 0)]$, monounsaturated fatty acids [MUFA $=\Sigma(\mathrm{C} 10: 1, \mathrm{C} 12: 1$, C14:1, cis-9 C16:1, trans-9 C16 :1, C17:1, trans-4 $\mathrm{C} 18: 1$, trans-5 C18:1, trans-6 C18:1, trans-9 C18:1, trans-10 C18:1, trans-11 C18:1, trans-12 C18:1, cis-9 18:1, cis-11 C18:1, cis-12 C18:1, cis-13 C18:1, cis-14 18:1, trans-15 C18:1)], and polyunsaturated fatty acids [PUFA $=\Sigma($ trans-11, cis-15 C18:2, C18 :2, C18:2 n-6, C18:3 n-3, cis-9,trans-11 C18:2, trans-9,cis-11 C18:2, trans-10, cis-12 C18:2, C22:6 n-3)].

\section{Data Handling and Statistical Analysis}

Descriptive statistics and tests of significance were done using PROC MEANS and PROC FREQ of SAS (2010; SAS Institute Inc., Cary, NC). The distribution of all variables was checked to approximate the normal Gaussian distribution. If necessary, a Box-Cox transformation (Box and Cox, 1964) was performed. This transformation was carried out for serum albumin, AST, BHBA, GGT, and NEFA, and for follicular BHBA, glucose, and NEFA variables. Subsequently, the data were analyzed as a randomized complete block design using the MIXED procedure (SAS Institute Inc., Cary, NC). The statistical model included the fixed effect treatment as the main variable of interest, as well as time, parity, and the interaction between time and treatment. Repeated measures (d) within cow were taken into account by adding cow as random effect. All variables were subjected to the autoregressive order $1[\mathrm{AR}(1)]$ covariance structure as determined by the largest Schwarz's Bayesian criterion and Akaike's information criterion. Significance and tendency were declared at $P<0.05$ and $0.1<P<0.05$, respectively. Interactions were removed from the final model when $P>0.15$. Data are reported as reduced model least squares means with pooled standard errors unless indicated otherwise. Pearson correlations (r) were calculated using the CORR procedure (SAS Institute Inc.) for metabolites within and between serum and FF.

\section{RESULTS}

The planned duration of prepartum concentrate feeding of $14 \mathrm{~d}$ eventually extended to $20 \mathrm{~d}$ due to unpredictable differences between the expected and actual calving dates of the cows. The prepartum supplementation period did not differ between treatments (ALG: 23 $\mathrm{d} \pm 4 \mathrm{SD}$; CON: $17 \mathrm{~d} \pm 6 \mathrm{SD}$ ) and parity (PRIM: $19 \mathrm{~d}$ \pm 9 SD; MULT: $21 \mathrm{~d} \pm 4$ SD; $P>0.05)$.

\section{Animal Characteristics}

The BCS did not significantly differ between the ALG $(3.02 \pm 0.05 \mathrm{SD})$ and CON $(2.98 \pm 0.08 \mathrm{SD}, P>$
$0.05)$ during the experiment. The BCS was dependent on time relative to calving, decreasing from calving to its nadir in wk 5 postpartum $(P<0.001)$. No interaction was found between treatment and week.

\section{Milk Production Characteristics}

Effects of algae supplementation on weekly milk production characteristics are presented in Table 2 . Supplementation (ALG) increased milk yield $(P=$ $0.054)$ and decreased milk fat yield $(P=0.007)$ and milk fat content $(P=0.015)$. Protein yield $(P=0.465)$ and FPCM $(P=0.192)$ were not affected by ALG supplementation, whereas a tendency for decreased milk protein content $(P=0.097)$ was observed (Table 2$)$. The number of daily milkings per cow in the automated voluntary milking system did not differ between treatments $(P=0.229)$. Dietary effects on milk production characteristics were independent of week after parturition (treatment $\times$ time, $P>0.1$; Table 2), although dietary effects were small during the first 2 wk of lactation.

\section{Milk Fatty Acid Composition}

Treatment effects on milk fatty acid composition are presented in Table 3. Proportions of SCFA decreased $(P<0.05)$ with ALG, whereas $\mathrm{C} 4: 0$ was not affected (ALG $3.84 \pm 0.15$ vs. CON $4.13 \pm 0.14 ; P>0.05)$. The decreased proportions of SCFA were not observed during the first $3 \mathrm{wk}$ of lactation, resulting in a significant treatment $\times$ time interaction $(P<0.05)$. Proportions of MCFA and LCFA were not significantly altered with ALG. Supplementation resulted in marked alterations in milk $\mathrm{C} 18$ FA composition, changes that were characterized as decreases $(P<0.05)$ in $\mathrm{C} 18: 0$, cis-9 C18:1, and cis-12 C18:1 $(0.22 \pm 0.019$ vs. $0.34 \pm 0.017 ; P<$ $0.001)$ and increases in trans $\mathrm{C} 18: 1$ (11.6 \pm 0.67 vs. $2.72 \pm 0.60 ; P<0.001)$, trans-11, cis- 15 C18:2 (0.26 \pm 0.026 vs. $0.077 \pm 0.024 ; P<0.001)$, cis -9 , trans -11 C18:2, trans-9,cis-11 C18:2, and trans-10,cis-12 C18:2 concentrations. Dietary effects on proportion of C18 FA in milk fat were generally independent of week of lactation, and effects were observed from the first week of lactation. Nevertheless, differences between dietary treatments in trans-10 18:1, cis-9,trans-11 18:2, and trans-9,cis-11 18:2 were smaller during the first weeks of lactation (Vlaeminck et al., 2009). Milk from cows receiving ALG had greater concentrations of 22:6 n-3 in milk fat (Table 3).

\section{Blood Serum and Plasma Metabolites}

Plasma and serum metabolites did not differ between treatments except for a tendency for a higher urea con- 
Table 2. Effect of dietary treatment on production characteristics, composition of milk in the first 12 wk of lactation, and BCS $(\mathrm{n}=16)^{1}$

\begin{tabular}{|c|c|c|c|c|c|c|}
\hline \multirow[b]{2}{*}{ Item } & \multicolumn{2}{|c|}{ Treatment $^{2}$} & \multirow[b]{2}{*}{$\mathrm{SEM}^{3}$} & \multicolumn{3}{|c|}{$P$-value } \\
\hline & $\mathrm{CON}$ & ALG & & $\begin{array}{l}\text { Treatment } \\
\text { (Trt) }\end{array}$ & Trt $\times$ Time & Time \\
\hline Milk, $\mathrm{kg} / \mathrm{d}$ & 38.2 & 41.2 & 1.08 & 0.054 & 0.139 & $<0.001$ \\
\hline $\begin{array}{l}\text { FPCM, }{ }^{,} \mathrm{kg} / \mathrm{d} \\
\text { Milk fat }\end{array}$ & 37.7 & 35.8 & 1.03 & - & - & - \\
\hline $\begin{array}{l}\mathrm{g} / \mathrm{kg} \\
\mathrm{kg} / \mathrm{d}\end{array}$ & $\begin{array}{l}40.7 \\
1.493\end{array}$ & $\begin{array}{l}31.6 \\
1.181\end{array}$ & $\begin{array}{l}2.33 \\
75.3\end{array}$ & $\begin{array}{l}0.015 \\
0.007\end{array}$ & $-\overline{0.121}$ & $\begin{array}{r}<0.001 \\
0.013\end{array}$ \\
\hline Milk protein & & & & & & \\
\hline $\begin{array}{l}\mathrm{g} / \mathrm{kg} \\
\mathrm{kg} / \mathrm{d}\end{array}$ & $\begin{array}{l}34.7 \\
1.301\end{array}$ & $\begin{array}{l}32.8 \\
1.336\end{array}$ & $\begin{array}{l}0.78 \\
34.6\end{array}$ & 0.097 & - & $<0.001$ \\
\hline Milkings & & & & & & \\
\hline no./d & 2.15 & 2.41 & 0.14 & - & - & - \\
\hline BCS & 2.98 & 3.02 & 0.05 & - & - & $<0.001$ \\
\hline
\end{tabular}

${ }^{1}$ Values are reduced model least squares means.

${ }^{2} \mathrm{CON}=$ control group; $\mathrm{ALG}=$ algae group.

${ }^{3}$ Pooled standard error of the mean.

${ }^{4}$ Fat- and protein-corrected milk.

centration in the serum of ALG cows $(P=0.075)$. None of the blood parameters showed a significant treatment $\times$ time interaction (Table 4). A significant time effect was found for all serum and plasma metabolites except urea $(P=0.09)$, BHBA $(P>0.1)$, and albumin $(P$ $>0.1$ ). Serum NEFA, AST, and GH peaked around parturition only to decrease after calving, whereas cholesterol, glucose, IGF-1, and insulin followed an opposite change, increasing after calving $(P<0.05)$. The concentrations of total protein and GGT gradually increased over time from the week before parturition.

\section{FF Metabolites}

On average, $1.10 \pm 0.33$ follicles were aspirated per cow and per session. Because of atresia (based on the $\mathrm{E} 2$ and $\mathrm{P} 4$ concentrations in the FF) or blood contamination, $14 \%$ of $\mathrm{FF}$ samples were excluded from further analysis. The number of excluded FF samples did not differ between treatments.

Marine algae supplementation increased the concentration of BHBA in the FF of ALG compared with CON $(P=0.04 ;$ Figure 1$)$; BHBA concentration peaked in

Table 3. Main effects of dietary treatment on fatty acids (FA) composition in milk fat ${ }^{1}$

\begin{tabular}{|c|c|c|c|c|c|c|}
\hline \multirow[b]{2}{*}{$\begin{array}{l}\mathrm{FA}, \mathrm{g} / 100 \mathrm{~g} \\
\text { of total FA }\end{array}$} & \multicolumn{2}{|c|}{ Treatment $^{2}$} & \multirow[b]{2}{*}{$\mathrm{SEM}^{3}$} & \multicolumn{3}{|c|}{$P$-value } \\
\hline & $\mathrm{CON}$ & ALG & & $\begin{array}{l}\text { Treatment } \\
\text { (Trt) }\end{array}$ & Trt $\times$ Time & Time \\
\hline Short-chain FA & 7.56 & 6.66 & 0.27 & 0.038 & 0.012 & 0.442 \\
\hline Medium-chain FA & 18.23 & 16.96 & 0.71 & - & 0.109 & $<0.001$ \\
\hline Long-chain FA & 43.7 & 44.5 & 1.2 & - & 0.002 & $<0.001$ \\
\hline Saturated FA & 63.8 & 55.5 & 1.2 & $<0.001$ & 0.002 & $<0.001$ \\
\hline Monounsaturated FA & 31.2 & 37.1 & 1.1 & 0.002 & 0.008 & $<0.001$ \\
\hline Polyunsaturated FA & 2.93 & 4.22 & 0.16 & $<0.001$ & $<0.001$ & $<0.001$ \\
\hline $\mathrm{C} 16^{4}$ & 28.39 & 28.33 & 0.48 & - & - & $<0.001$ \\
\hline C18:0 & 11.4 & 5.70 & 0.51 & $<0.001$ & - & 0.035 \\
\hline cis-9 C18:1 & 23.1 & 18.6 & 1.0 & 0.009 & - & $<0.001$ \\
\hline trans-10 C18:1 & 0.42 & 4.28 & 0.51 & $<0.001$ & - & - \\
\hline trans-11 C18:1 & 1.25 & 4.54 & 0.21 & $<0.001$ & - & - \\
\hline trans-12 C18:1 & 0.51 & 1.42 & 0.08 & $<0.001$ & - & - \\
\hline C18:3 n-6 & 0.0184 & 0.0139 & 0.0015 & 0.048 & - & - \\
\hline C18:3 n-3 & 0.496 & 0.457 & 0.021 & - & - & - \\
\hline cis-9,trans-11 C18:2 & 0.487 & 1.360 & 0.099 & $<0.001$ & 0.016 & 0.005 \\
\hline trans-9,cis-11 C18:2 & 0.0105 & 0.0729 & 0.0080 & $<0.001$ & 0.052 & 0.031 \\
\hline trans-10, cis-12 C18:2 & 0.0032 & 0.0097 & 0.0012 & 0.002 & - & - \\
\hline $\mathrm{C} 22: 6 \mathrm{n}-3$ & 0.013 & 0.196 & 0.016 & $<0.001$ & - & - \\
\hline
\end{tabular}

${ }^{1}$ Values are reduced model least squares means.

${ }^{2} \mathrm{CON}=$ control group; ALG = algae group.

${ }^{3}$ Pooled standard error of the mean.

${ }^{4} \mathrm{C} 16: 0+$ cis-9 C16:1. 
Table 4. Effect of dietary treatment on serum or plasma metabolite concentrations during the first 6 wk of lactation $(\mathrm{n}=16)^{1}$

\begin{tabular}{|c|c|c|c|c|c|c|}
\hline \multirow[b]{2}{*}{ Item } & \multicolumn{2}{|c|}{ Treatment $^{2}$} & \multirow[b]{2}{*}{$\mathrm{SEM}^{3}$} & \multicolumn{3}{|c|}{$P$-value } \\
\hline & $\mathrm{CON}$ & ALG & & $\begin{array}{l}\text { Treatment } \\
\text { (Trt) }\end{array}$ & Trt $\times$ Time & Time \\
\hline Total cholesterol, mmol/L & 3.21 & 3.33 & 0.19 & - & - & $<0.001$ \\
\hline Urea, mmol/L & 4.69 & 5.13 & 0.17 & 0.075 & - & 0.091 \\
\hline Glucose, $\mathrm{mmol} / \mathrm{L}$ & 3.42 & 3.22 & 0.09 & - & - & 0.036 \\
\hline Total protein, $\mathrm{g} / \mathrm{L}$ & 81.2 & 77.5 & 1.9 & - & - & $<0.001$ \\
\hline NEFA, mmol/L & 0.309 & 0.323 & 0.054 & - & - & $<0.001$ \\
\hline $\mathrm{BHBA}, \mathrm{mmol} / \mathrm{L}$ & 0.732 & 0.880 & 0.082 & - & - & - \\
\hline$\gamma$-Glutamyltransferase, IU/L & 27.0 & 36.8 & 4.3 & - & - & 0.002 \\
\hline Aspartate aminotransferase, IU/L & 78.8 & 85.7 & 6.7 & - & - & $<0.001$ \\
\hline Albumin, g/L & 29.72 & 30.45 & 0.51 & - & - & - \\
\hline Growth hormone, ng/mL & 5.53 & 4.57 & 0.33 & - & - & $<0.001$ \\
\hline IGF-1, ng/mL & 70.1 & 77.2 & 7.9 & - & - & $<0.001$ \\
\hline Insulin, IU/L & 1.68 & 1.57 & 0.14 & - & - & 0.002 \\
\hline
\end{tabular}

${ }^{1}$ Values are reduced model least squares means.

${ }^{2} \mathrm{CON}=$ control group, $\mathrm{ALG}=$ algae group.

${ }^{3}$ Pooled standard error of the mean.

both groups around d 33. Total protein concentration was decreased in FF of ALG but increased over time after calving. The concentration of cholesterol in FF also increased over time $(P<0.001)$, and the significant interaction with treatment $(P=0.042$; Table 5$)$ was caused by a decreased cholesterol concentration on d 46 for the ALG compared with CON (Figure 2). An increase over time was registered for total protein $(P<$ $0.001)$ and IGF-1 $(P=0.0011)$. The concentration of NEFA tended to decrease over time $(P=0.063$; Figure $3)$.

\section{Correlations Between Blood and FF Metabolites}

Strong correlations between serum and FF were calculated for BHBA $(\mathrm{r}=0.78 ; P<0.001)$, glucose $(\mathrm{r}=$ $0.76 ; P<0.001)$, and urea $(\mathrm{r}=0.81 ; P<0.001)$. Lower Pearson correlations between these fluids were apparent for albumin $(\mathrm{r}=0.64 ; P<0.001)$, total protein $(\mathrm{r}$ $=0.69 ; P<0.001)$, and total cholesterol $(\mathrm{r}=0.57 ; P$ $<0.001)$. When comparing different metabolites within serum or FF, BHBA and glucose in serum $(\mathrm{r}=-0.64$; $P<0.001)$ and FF $(\mathrm{r}=-0.63 ; P<0.001)$ were negatively correlated. A similar negative correlation existed between $\mathrm{GH}$ and total cholesterol in the serum $(\mathrm{r}=$ $-0.51 ; P<0.001$ ), whereas in FF, IGF-1 and glucose were positively correlated $(\mathrm{r}=0.58 ; P<0.001)$.

\section{DISCUSSION}

\section{Effect of Marine Algae Supplementation on Milk Production Parameters in Early Lactation}

In this experiment, MFD was induced by daily intake of $44 \mathrm{~g}$ of DHA from marine algae (Schizochytrium spp.), as described earlier by Franklin et al. (1999) and Boeckaert et al. (2008), who fed, respectively, 37.6 and 43.7 $\mathrm{g} / \mathrm{d}$ of DHA to mid-lactating dairy cows. The decreased milk fat yield and content observed here are consistent with Boeckaert et al. (2008) (47.9 vs. $22.5 \mathrm{~g} / \mathrm{kg}$ and 1.27 vs. $0.52 \mathrm{~kg} / \mathrm{d}$ ) and Franklin et al. (1999) (37.0 vs. $29.5 \mathrm{~g} / \mathrm{kg}$ and 0.84 vs. $0.69 \mathrm{~kg} / \mathrm{d}$ ). Studies that included marine products such as fish oil (Donovan et al., 2000) and fish meal (AbuGhazaleh et al., 2004) reported similar findings of decreased milk fat yield. As in the study of Franklin et al. (1999), which was the first one using ALG in dairy cows, the present study demonstrated a tendency for decreased milk protein content in the ALG group (34.7 vs. 32.8 g/kg). Franklin et al. (1999) did not increase milk yield nor FPCM by feeding algae supplement, whereas milk yield increased by $8.1 \%$ in the current study. Mattos et al. (2004) fed $200 \mathrm{~g}$ of fish oil $[72 \mathrm{~g} / \mathrm{d}$ of eicosapentaenoic acid (EPA) and $56 \mathrm{~g} / \mathrm{d}$ of DHA] to early-lactation dairy cows compared with an isoenergetic, isonitrogenous, and isolipidic ration containing olive oil. They reported decreased milk fat yield (1.27 vs. $0.81 \mathrm{~kg} / \mathrm{d})$ for the group supplemented with fish oil. Milk production was recorded in the first 3 wk after parturition and did not differ between groups, which is similar to the limited effect of treatment on milk production in the first 2 wk in the present study. In the study of Mattos et al. (2004), large numerical differences in DMI and milk yield were recorded, although these were not significant. Hence, responses of milk yield on energy sparing through ALG-induced MFD differed considerably between studies, probably because of differences in lactation stage of cows in our experiment compared with others (Franklin et al., 1999; Boeckaert et al., 2008), as comprehensively postulated by Friggens et al. (2010). 
Table 5. Effect of dietary treatment on follicular fluid metabolite concentrations during the first 6 wk of lactation $(\mathrm{n}=16)^{1}$

\begin{tabular}{|c|c|c|c|c|c|c|}
\hline \multirow[b]{2}{*}{ Item } & \multicolumn{2}{|c|}{ Treatment $^{2}$} & \multirow[b]{2}{*}{$\mathrm{SEM}^{3}$} & \multicolumn{3}{|c|}{$P$-value } \\
\hline & $\mathrm{CON}$ & ALG & & $\begin{array}{c}\text { Treatment } \\
\text { (Trt) }\end{array}$ & Trt $\times$ Time & Time \\
\hline Total cholesterol, mmol/L & 1.548 & 1.339 & 0.081 & - & 0.042 & $<0.001$ \\
\hline Urea, $\mathrm{mmol} / \mathrm{L}$ & 4.63 & 4.88 & 0.18 & - & - & - \\
\hline Glucose, $\mathrm{mmol} / \mathrm{L}$ & 3.414 & 3.273 & 0.099 & - & - & $<0.001$ \\
\hline Total protein, $\mathrm{g} / \mathrm{L}$ & 67.6 & 62.9 & 1.7 & 0.053 & - & 0.007 \\
\hline NEFA, mmol/L & 0.218 & 0.193 & 0.035 & - & - & 0.063 \\
\hline BHBA, mmol/L & 0.718 & 0.992 & 0.088 & 0.043 & - & 0.072 \\
\hline Albumin, $\mathrm{g} / \mathrm{L}$ & 28.56 & 28.59 & 0.50 & - & - & - \\
\hline IGF-1, ng/mL & 70.1 & 67.0 & 4.6 & - & - & 0.001 \\
\hline Insulin, IU/L & 1.74 & 1.33 & 0.22 & - & - & - \\
\hline
\end{tabular}

${ }^{1}$ Values are reduced model least squares means.

${ }^{2} \mathrm{CON}=$ control group, $\mathrm{ALG}=$ algae group.

${ }^{3}$ Pooled standard error of the mean.

\section{MFD in Relation to Biochemical Parameters of the Energy Balance in Blood and Follicular Fluid}

The induction of MFD has been proposed (Shingfield et al., 2004; Kay et al., 2006) and proven (Odens et al., 2007 ) to reduce NEBAL in dairy cows early postpartum. All researchers focused mainly on the decreased energy loss via the energetically most expensive component synthesized in milk ( $50 \%$ of total milk energy), milk fat, which happens to be the milk component most easily controlled by dietary management (Odens et al.,
2007). Feeding trans-10,cis-12 CLA, a potent milk fat depressing isomer of CLA (Baumgard et al., 2002), in early lactation improved the calculated energy balance (EBAL) in early lactation in the study of Kay et al. (2006). This could not be confirmed by any of the reported biochemical markers in the blood plasma to estimate EBAL (BHBA, glucose, insulin, or NEFA). So far, we are aware of only one study (Odens et al., 2007) showing marked results on energy balance. In that study, MFD was induced (a decrease of $26 \%$ in milk fat content and $23 \%$ in milk fat yield) from 8

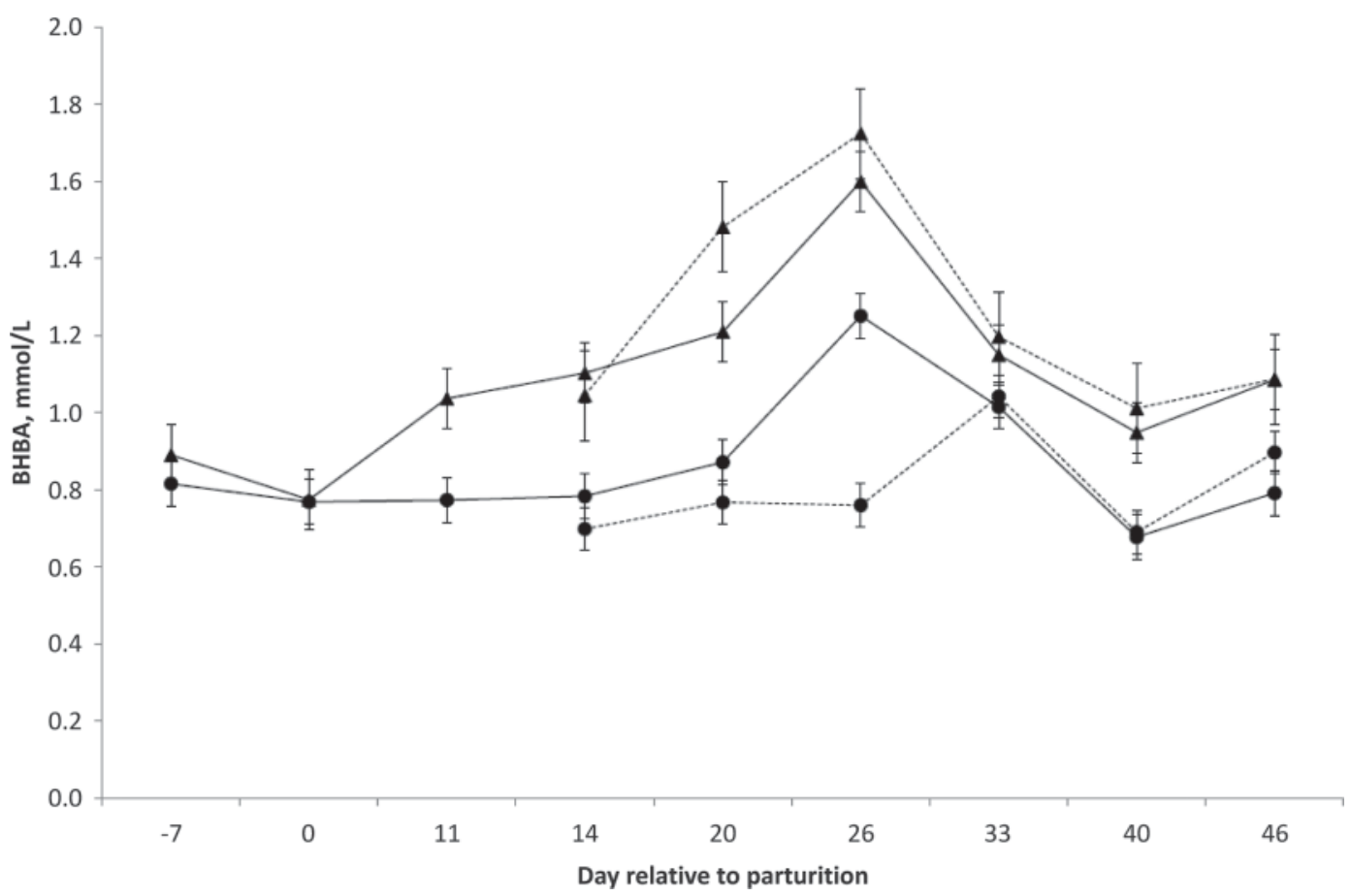

Figure 1. Profiles of serum (solid lines) and follicular (dotted lines) BHBA concentrations of periparturient cows fed the control diet ( $)$ ) or marine algae $\operatorname{diet}(\mathbf{\Lambda})$. 


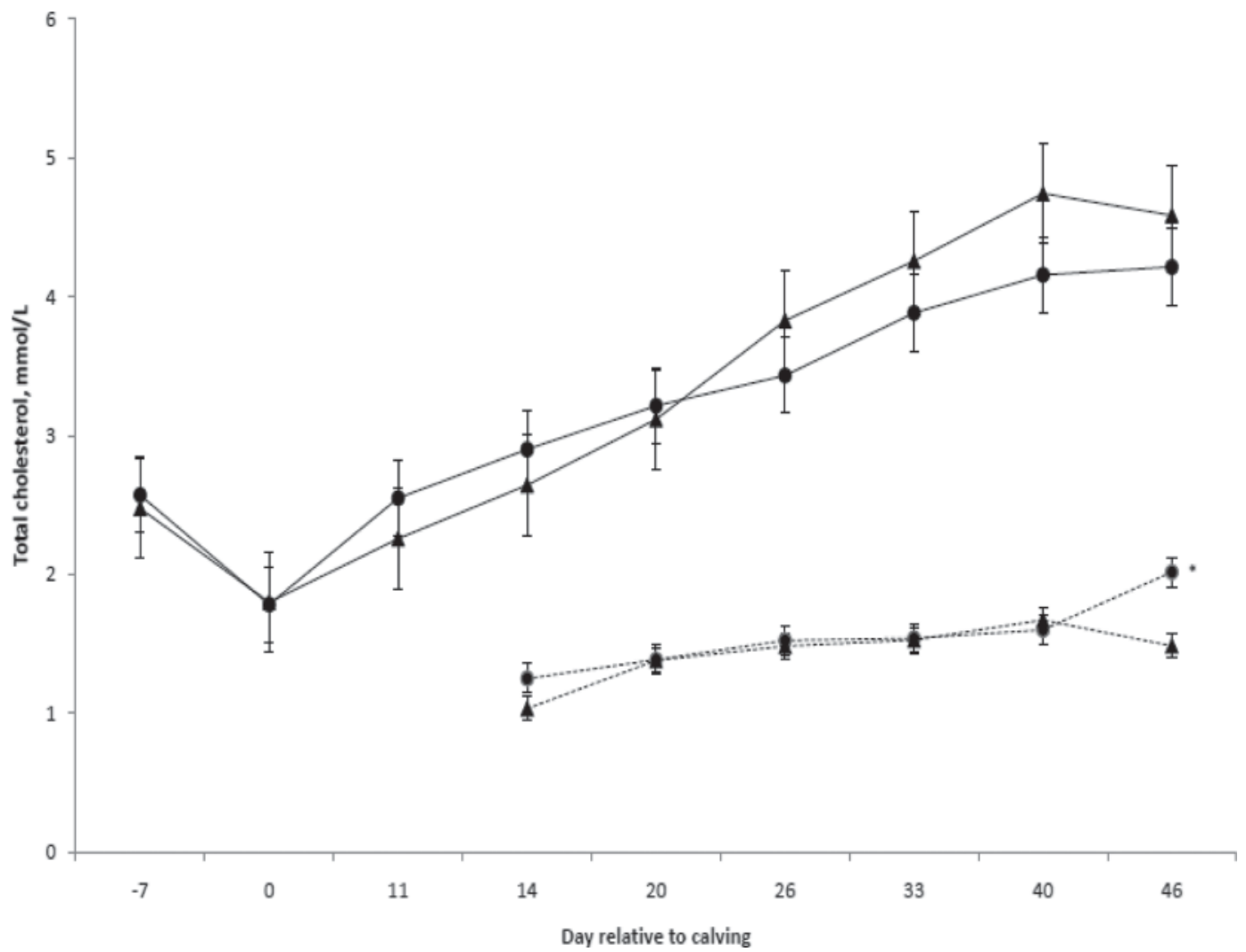

Figure 2. Profiles of plasma (solid lines) and follicular (dotted lines) total cholesterol concentrations of periparturient cows fed the control $\operatorname{diet}(\bullet)$ or marine algae $\operatorname{diet}(\mathbf{\Lambda})$.

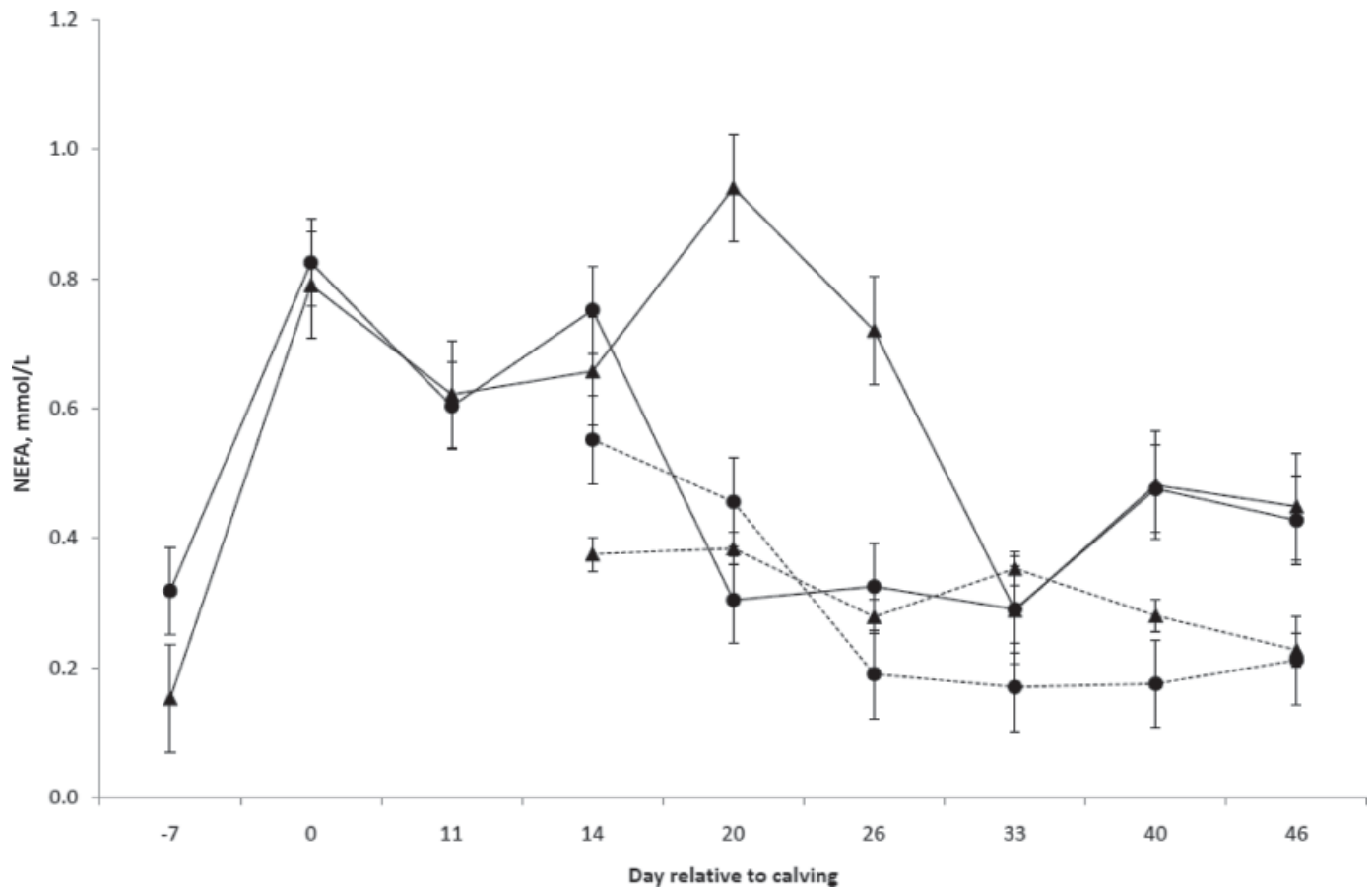

Figure 3. Profiles of plasma (solid lines) and follicular (dotted lines) NEFA concentrations of periparturient cows fed the control diet (•) or marine algae diet $(\mathbf{\Lambda})$. 
DIM using a diet containing $600 \mathrm{~g}$ of rumen-inert CLA supplement with $29 \mathrm{~g}$ of trans-10,cis-12 CLA. Those researchers were able to show a significant decrease of $12 \%$ in NEFA and an increase of $11 \%$ in glucose concentration early postpartum in the CLA-supplemented group, indicating improved energetic status of these cows.

Regarding marine products, Mattos et al. (2004) noted a MFD (a 36\% decrease in milk fat yield) induced by supplementing $18 \mathrm{~g} / \mathrm{kg}$ of DM of fish oil postpartum (72 $\mathrm{g} / \mathrm{d}$ of EPA and $56 \mathrm{~g} / \mathrm{d}$ of DHA) compared with olive oil without any effect on milk yield or milk protein content or yield. Nevertheless, in that study, postpartum DMI significantly decreased by $18 \%$, which could obviously interfere with EBAL parameters, leading to increasing BHBA at d 10 and 13 and lower glucose concentrations but no effect on blood plasma NEFA. Because of the experimental design of the present study, no individual DMI were recorded and hence, dietary effects on DMI cannot be excluded. However, maintained glucose, insulin, GH, and IGF-1 blood concentrations and a lack of NEFA increase despite the greater milk production does not suggest DMI impairment. The concentration of BHBA increased in $\mathrm{FF}$, although the increase in serum was not significant. Nevertheless, BHBA concentrations in both compartments were strongly correlated (Figure 1). The increase in milk yield in the current experiment might have induced an enlarged need of the ALG cow's metabolism for glucose, pushing her to switch the hepatic pathways converting glucogenic amino acids into glucose (Drackley et al., 2001). This could explain the tendency for increased urea concentration measured in the serum of ALG cows. A positive effect on blood energy parameters, in particular increased blood glucose (Moussavi et al., 2007; Ballou et al., 2009) and insulin (Moussavi et al., 2007) concentrations as well as decreased BHBA (Ballou et al., 2009), was reported when supplementing EPA + DHA. Supplementing EPA + DHA from fish meal $(23.2 \mathrm{~g} / \mathrm{d}$; Moussavi et al., 2007) but not from fish oil (46.7 g/d, Ballou et al., 2009) was associated with increased milk yield.

\section{Correlation Between Blood and FF Biochemical Parameters of EBAL}

In the current trial, NEFA peaked in the serum but not in FF $20 \mathrm{~d}$ after calving (Figure 3), which is also reflected in the smaller coefficient of variation in $\mathrm{FF}$ (0.69) compared with serum (0.83). Our results are similar to those of Leroy et al. (2004) and substantiate the probable existence of a protective mechanism of the follicular wall against high blood NEFA concentrations. However, this mechanism does not hold for the smaller BHBA molecule (molar mass: $104.1 \mathrm{~g} / \mathrm{mol}$ ).
Elevated follicular BHBA concentrations as observed in the current experiment are similar to those found under (sub-) ketotic conditions during NEBAL, which were mimicked in bovine in vitro maturation models by Leroy et al. (2006). They proved that these elevated BHBA concentrations, in particular when combined with low follicular glucose concentrations, which is also the case in the current experiment, are detrimental to the oocyte's developmental capacity. Finally, the decrease of FF protein through ALG feeding should not be neglected. Even though the presence of protein seems necessary for normal in vitro fertilization (Eckert and Niemann, 1995), changes in FF protein concentration did not affect developmental capacity of oocytes in beef heifers (Iwata et al., 2006). However, to the best of our knowledge, the effect of FF protein levels on fertility of high-yielding cows has not yet been reported.

\section{Nutrient Sparing and Redirection Through MFD: A Caloric and Metabolic Approach}

In the present trial, a daily ME sparing effect of 3.48 Mcal was obtained due to the MFD of $313 \mathrm{~g} / \mathrm{d}$ (11 Mcal/kg of milk fat; Dado et al., 1993). Assuming an $\mathrm{ME}$ requirement for lactose and protein production of 5.11 and $6.43 \mathrm{Mcal} / \mathrm{kg}$, respectively (Dado et al., 1993), the ME sparing of $3.48 \mathrm{Mcal}$ could theoretically lead to an increase in milk yield of $7.43 \mathrm{~kg} / \mathrm{d}$, which is higher than the $3 \mathrm{~kg} / \mathrm{d}$ increase observed in our current experiment (Table 6). This most probably is due to a limiting nutrient availability in early lactation (Drackley et al., 2001). Therefore, calculation of nutrient availability (e.g., glucose) and requirement possibly is a better approach (Dado et al., 1993) to explain differences in milk yield. The 2 main substrates required for milk fat synthesis are acetate $(62 \%)$ and propionate $(26 \%$; Dado et al., 1993). The molar mass of milk fat was calculated based on the fatty acid profile, respectively, as 786 and $793 \mathrm{~g} / \mathrm{mol}$ for CON and ALG. In the current trial, milk fat production was decreased by $0.411 \mathrm{~mol}$ of milk fat due to the MFD, which saved $6.47 \mathrm{~mol}$ of acetate, $2.71 \mathrm{~mol}$ of propionate, $0.205 \mathrm{~mol}$ of glycerol, $0.476 \mathrm{~mol}$ of LCFA, and $0.3 \mathrm{~mol}$ of BHBA (Dado et al., 1993; Table 6). The fate of excess propionate might be easy to follow because hepatic gluconeogenesis lags in early lactation due to a lack of substrate (Overton et al., 1999; Drackley et al., 2001). Assuming an overall turnover efficiency of propionate via glucose to lactose of 0.55 (Lemosquet et al., 2009), theoretically the extra supply of $2.71 \mathrm{~mol}$ of propionate could be converted into $0.414 \mathrm{~mol}$ of lactose. Because milk volume and lactose production are linked via an osmotic pressure mechanism (Linzell and Peaker, 1971), this could lead to an increased milk yield of $2.95 \mathrm{~kg} / \mathrm{d}$ (48 
Table 6. Caloric and metabolic approach to milk fat depression (MFD)

\begin{tabular}{|c|c|c|c|c|}
\hline Item & \multicolumn{4}{|c|}{$\operatorname{Diet}^{1}$} \\
\hline \multicolumn{5}{|l|}{ Caloric MFD } \\
\hline Milk yield, $\mathrm{kg} / \mathrm{d}$ & 41.2 & \multirow[b]{3}{*}{$\begin{array}{l}\text { ALG: } 793 \mathrm{~g} / \mathrm{mol}^{2} \\
\text { CON: } 786 \mathrm{~g} / \mathrm{mol}^{2}\end{array}$} & \multicolumn{2}{|c|}{38.2} \\
\hline Fat yield, $\mathrm{g} / \mathrm{d}$ & 1.181 & & \multicolumn{2}{|c|}{1.493} \\
\hline Fat yield, mol/d & 1.49 & & \multicolumn{2}{|c|}{1.90} \\
\hline Energy available for increased milk production & \multicolumn{4}{|c|}{$\begin{array}{l}=16.1-12.6 \\
=3.48 \mathrm{Mcal} \\
=\mathrm{kg} \text { of milk } \times(6.43 \mathrm{Mcal} / \mathrm{kg} \text { of milk protein } \\
+5.11 \mathrm{Mcal} / \mathrm{kg} \text { of milk lactose })^{3} \\
=7.43 \mathrm{~kg} \text { of milk }\end{array}$} \\
\hline \multicolumn{5}{|c|}{ - } \\
\hline Fat yield, mol/d & 1.49 & & 1.90 & Ratio \\
\hline $\begin{array}{l}\text { BHBA requirement for de novo milk fat synthesis, mol/d } \\
\text { BHBA }_{\mathrm{SERUM}},{ }^{\mathrm{mmol}} / \mathrm{L} \\
\mathrm{BHBA}_{\mathrm{FF}},{ }^{\mathrm{m}} \mathrm{mmol} / \mathrm{L}\end{array}$ & $\begin{array}{l}1.09 \\
0.88 \\
0.99\end{array}$ & $0.73 \mathrm{~mol} / \mathrm{mol}^{3}$ & $\begin{array}{l}1.39 \\
0.73 \\
0.72\end{array}$ & $\begin{array}{l}0.78 \\
1.20 \\
1.38\end{array}$ \\
\hline \multicolumn{5}{|c|}{$\begin{array}{l}{ }^{1} \mathrm{ALG}=\text { algae group; } \mathrm{CON}=\text { control group; } \mathrm{CF}=\text { conversion factor. } \\
{ }^{2} \text { Weighted mean molar mass based on the } \mathrm{CON} \text { and ALG fatty acid profiles. } \\
{ }^{3} \mathrm{ME} \text { (Dado et al., 1993); for energy available for increased milk production: milk protein }=34.7 \mathrm{~g} / \mathrm{kg} \text { and milk lactose }=48 \mathrm{~g} / \mathrm{kg} \text {. } \\
{ }^{4} \text { Lemosquet et al. }(2009) . \\
{ }^{5} \mathrm{BHBA} \text { in the serum. }\end{array}$} \\
\hline
\end{tabular}

g of lactose $/ \mathrm{kg}$ of milk), which matches the $3.00 \mathrm{~kg} / \mathrm{d}$ increase in milk production observed in the present study. Until now, research has not been able to clarify the pathway by which the unused acetate and LCFA are metabolized when milk fat is depressed. Although not quantified in early lactating dairy cows, increased lipogenesis seems the most plausible route (Harvatine et al., 2009). Although making a small contribution compared with propionate, glycerol contributes 0.15 to 0.20 of the glucose demand at d 4 postpartum (Bell, 1995). The MFD in the current trial saved $0.205 \mathrm{~mol}$ of glycerol (molar mass: $92.1 \mathrm{~g} / \mathrm{mol}$ ) daily, which equals $18.9 \mathrm{~g} / \mathrm{d}$ of glycerol. However, this is minor compared with the glycerol released during extensive mobilization of adipose tissue in early lactation (up to $433 \mathrm{~g} / \mathrm{d}$; Drackley et al., 2001). Finally, de novo synthesis of SCFA requires $0.5 \mathrm{~mol}$ of BHBA per mole of fatty acid (Dado et al., 1993). Taking into account the milk fatty acid profile of milk in the current trial (Table 3), ALG depressed fat synthesis by $1.23 \mathrm{~mol}$ of $\mathrm{FA} / \mathrm{d}$, saving
0.3 mol of BHBA (Dado et al., 1993), which represents about 0.78 of the BHBA requirement for milk fatty acid production in the CON. The unused BHBA surplus might be the origin of the 1.2- to 1.4-fold BHBA concentration in blood serum $(0.88 / 0.73=1.20$; Table $3)$ and FF $(0.99 / 0.72=1.38$; Table 4$)$ of ALG cows compared with CON cows. Furthermore, higher butyrate production in the rumen, as suggested from rumen fatty acid proportions of ALG-fed cows (Boeckaert et al., 2008), could have contributed to higher BHBA in blood and FF as observed in the current trial. Hence, the approach of taking both metabolic limitations and nutrient requirements in early lactation into account seems to better explain observations seen during MFD in high-yielding dairy cows.

\section{CONCLUSIONS}

Santos et al. (2008) stated that improved reproductive performance has not been consistently observed 
when feeding fatty acids to dairy cattle especially when accompanied by increased milk yield and a loss in body weight. The results from the current study substantiate this statement, because increased BHBA concentrations in $\mathrm{FF}$ that have been associated with poor reproductive performance in high-yielding dairy cows were detected in the PUFA-supplemented group (ALG). However, when calculating nutrient requirements during MFD in early lactation, increased BHBA concentrations can be attributed to a nutrient-saving effect at the udder level. In conclusion, the downregulation of de novo milk fat synthesis has 2 main consequences. The first is increased milk production most likely caused by a propionate-saving effect when milk fat is depressed and the second is increased BHBA concentration in the FF that cannot be attributed to a worsened energy status of the animals as all other indicators contradict any change in EBAL. This second finding suggests that BHBA might not be an appropriate metabolic parameter to estimate the EBAL in early lactating dairy cows during MFD.

\section{ACKNOWLEDGMENTS}

The authors thank J. P. Balis, K. Devriendt, B. Theeuwes, and C. Melis (all from the Laboratory for Animal Nutrition and Animal Product Quality, Faculty of Bioscience Engineering, Ghent University Melle, Belgium) for their excellent technical support. Bruno Vlaeminck is a postdoctoral fellow of the Fund for Scientific Research-Flanders (Belgium). This research was funded by the Institute for the Promotion of Innovation by Science and Technology in Flanders (grant no. 050683$)$.

\section{REFERENCES}

AbuGhazaleh, A. A., D. J. Schingoethe, A. R. Hippen, and K. F. Kalscheur. 2004. Conjugated linoleic acid increases in milk when cows fed fish meal and extruded soybeans for an extended period of time. J. Dairy Sci. 87:1758-1766.

Ballou, M. A., R. C. Gomes, S. O. Juchem, and E. J. DePeters. 2009. Effects of dietary supplemental fish oil during the peripartum period on blood metabolites and hepatic fatty acid compositions and total triacylglycerol concentrations of multiparous Holstein cows. J. Dairy Sci. 92:657-669.

Baumgard, L. H., E. Matitashvili, B. A. Corl, D. A. Dwyer, and D. E. Bauman. 2002. Trans-10, cis-12 conjugated linoleic acid decreases lipogenic rates and expression of genes involved in milk lipid synthesis in dairy cows. J. Dairy Sci. 85:2155-2163.

Bell, A. W. 1995. Regulation of organic nutrient metabolism during transition from late pregnancy to early lactation. J. Anim. Sci. 73:2804-2819.

Boeckaert, C., B. Vlaeminck, J. Dijkstra, A. Issa-Zacharia, T. Van Nespen, W. Van Straalen, and V. Fievez. 2008. Effect of dietary starch or micro algae supplementation on rumen fermentation and milk fatty acid composition of dairy cows. J. Dairy Sci. 91:47144727.

Box, G. E. P., and D. R. Cox. 1964. An analysis of transformations. J. R. Stat. Soc. B 26:211-252.

Britt, J. H. 1992. Impacts of early postpartum metabolism on follicular development and fertility. Pages 39-43 in Proc. 24th Annu. Conv. Am. Assoc. Bovine Pract. Am. Assoc. Bovine Pract., Auburn, AL.
Chouinard, P. Y., L. Corneau, D. M. Barbano, L. E. Metzger, and D. E. Bauman. 1999. Conjugated linoleic acids alter milk fatty acid composition and inhibit milk fat secretion in dairy cows. J. Nutr. 129:1579-1584.

Christie, W. W. 1982. A simple procedure for rapid transmethylation of glycerolipids and cholesteryl esters. J. Lipid Res. 23:1072-1075.

CVB. 2007. Tabellenboek Veevoeding 2000 (Dutch Feeding Tables). Voedernormen landbouwhuisdieren en voederwaarde veevoeders (in Dutch). Central Bureau for Livestock Feeding, Lelystad, the Netherlands.

Dado, R. G., D. R. Mertens, and G. E. Shook. 1993. Metabolizable energy and absorbed protein-requirements for milk component production. J. Dairy Sci. 76:1575-1588.

Dobson, H., R. F. Smith, M. D. Royal, C. H. Knight, and I. M. Sheldon. 2007. The high-producing dairy cow and its reproductive performance. Reprod. Domest. Anim. 42:17-23.

Donovan, D. C., D. J. Schingoethe, R. J. Baer, J. Ryali, A. R. Hippen, and S. T. Franklin. 2000. Influence of dietary fish oil on conjugated linoleic acid and other fatty acids in milk fat from lactating dairy cows. J. Dairy Sci. 83:2620-2628.

Drackley, J., H. Dann, G. Douglas, N. Guretzky, N. Litherland, J. Underwood, and J. Loor. 2005. Physiological and pathological adaptations in dairy cows that may increase susceptibility to periparturient diseases and disorders. Ital. J. Anim. Sci. 4:323-344.

Drackley, J. K., T. R. Overton, and G. N. Douglas. 2001. Adaptations of glucose and long-chain fatty acid metabolism in liver of dairy cows during the periparturient period. J. Dairy Sci. 84(Suppl E):E100-E112.

Eckert, J., and H. Niemann. 1995. In vitro maturation, fertilization and culture to blastocysts of bovine oocytes in protein-free media. Theriogenology 43:1211-1225.

Edmonson, A. J., I. J. Lean, L. D. Weaver, T. Farver, and G. Webster. 1989. A body condition scoring chart for Holstein dairy cows. J. Dairy Sci. 72:68-78.

European Community. 1993. Determination of crude protein. Directive no. L179/9 of the Commission of the European Communities of 22.07.93. Off. J. Eur. Com., Brussels, Belgium.

European Economic Community. 1971a. Determination of moisture. Directive no. L279/8 of the Commission of the European Communities of 20.12.71. Off. J. Eur. Com., Brussels, Belgium.

European Economic Community. 1971b. Determination of crude ash. Directive no. L155/20 of the Commission of the European Communities of 12.07.71. Off. J. Eur. Com., Brussels, Belgium.

Flemish Cattle Breeding Association. 2008. CRV Jaarstistieken. Flemish Cattle Breeding Association, Oosterzele, Belgium.

Franklin, S. T., K. R. Martin, R. J. Baer, D. J. Schingoethe, and A. R. Hippen. 1999. Dietary marine algae (Schizochytrium sp.) increases concentrations of conjugated linoleic, docosahexaenoic and transvaccenic acids in milk of dairy cows. J. Nutr. 129:2048-2054

Friggens, N. C., C. Disenhaus, and H. V. Petit. 2010. Nutritional sub-fertility in the dairy cow: Towards improved reproductive management through a better biological understanding. Animal 4:1197-1213.

Grummer, R. R. 2007. Strategies to improve fertility of high yielding dairy farms: Management of the dry period. Theriogenology 68:S281-S288

Harvatine, K. J., J. W. Perfield, and D. E. Bauman. 2009. Expression of enzymes and key regulators of lipid synthesis is upregulated in adipose tissue during CLA-induced milk fat depression in dairy cows. J. Nutr. 139:849-854.

Hendriksen, P. J. M., B. M. Gadella, P. L. A. M. Vos, E. Mullaart, T. A. M. Kruip, and S. J. Dieleman. 2003. Follicular dynamics around the recruitment of the first follicular wave in the cow. Biol. Reprod. 69:2036-2044.

Horan, B., J. F. Mee, P. O'Connor, A. Rath, and P. Dillon. 2005. The effect of strain of Holstein-Friesian cow and feeding system on postpartum ovarian function, animal production and conception rate to first service. Theriogenology 63:950-971.

ISO (International Organization for Standardization). 1999. Animal feeding stuffs-Determination of fat content. American National Standards Institute, New York, NY. 
Istasse, L., C. Vaneenaeme, A. Gabriel, A. Clinquart, G. Maghuinrogister, and J. M. Bienfait. 1990. The relationship between carcass characteristics, plasma hormones and metabolites in young fattening bulls. Vet. Res. Commun. 14:19-26.

Iwata, H., J. Inoue, K. Kimura, T. Kuge, T. Kuwayama, and Y. Monji. 2006. Comparison between the characteristics of follicular fluid and the developmental competence of bovine oocytes. Anim. Reprod. Sci. 91:215-223.

Jensen, R. G. 2002. The composition of bovine milk lipids: January 1995 to December 2000. J. Dairy Sci. 85:295-350.

Kay, J. K., J. R. Roche, C. E. Moore, and L. H. Baumgard. 2006. Effects of dietary conjugated linoleic acid on production and metabolic parameters in transition dairy cows grazing fresh pasture. J. Dairy Res. 73:367-377.

Lemosquet, S., G. Raggio, G. E. Lobley, H. Rulquin, J. Guinard-Flament, and H. Lapierre. 2009. Whole-body glucose metabolism and mammary energetic nutrient metabolism in lactating dairy cows receiving digestive infusions of casein and propionic acid. J. Dairy Sci. 92:6068-6082.

Leroy, J. L. M. R., T. Vanholder, J. R. Delanghe, G. Opsomer, A. Van Soom, P. E. J. Bols, J. Dewulf, and A. de Kruif. 2004. Metabolic changes in follicular fluid of the dominant follicle in high-yielding dairy cows early post partum. Theriogenology 62:1131-1143.

Leroy, J. L. M. R., T. Vanholder, B. Mateusen, A. Christophe, G. Opsomer, A. de Kruif, G. Genicot, and A. Van Soom. 2005. Nonesterified fatty acids in follicular fluid of dairy cows and their effect on developmental capacity of bovine oocytes in vitro. Reproduction 130:485-495.

Leroy, J. L. M. R., T. Vanholder, G. Opsomer, P. E. J. Bols, A. de Kruif, and A. Van Soom. 2006. The in vitro development of bovine oocytes after maturation in negative energy balance associated glucose and beta-hydroxybutyrate concentrations in dairy cows. Reprod. Domest. Anim. 41:119-123.

Linzell, J. L., and M. Peaker. 1971. Mechanism of milk secretion. Physiol. Rev. 51:564-597.

Lucy, M. C. 2001. Reproductive loss in high-producing dairy cattle: Where will it end? J. Dairy Sci. 84:1277-1293.

Mattos, R., C. R. Staples, A. Arteche, M. C. Wiltbank, F. J. Diaz, T. C. Jenkins, and W. W. Thatcher. 2004. The effects of feeding fish oil on uterine secretion of PGF2alpha, milk composition, and metabolic status of periparturient Holstein cows. J. Dairy Sci. $87: 921-932$.

Moussavi, A. R. H., R. O. Gilbert, T. R. Overton, D. E. Bauman, and W. R. Butler. 2007. Effects of feeding fish meal and n-3 fatty ac- ids on milk yield and metabolic responses in early lactating dairy cows. J. Dairy Sci. 90:136-144.

O'Callaghan, D., and M. P. Boland. 1999. Nutritional effects on ovulation, embryo development and the establishment of pregnancy in ruminants. Anim. Sci. 68:299-314.

Odens, L. J., R. Burgos, M. Innocenti, M. J. VanBaale, and L. H. Baumgard. 2007. Effects of varying doses of supplemental conjugated linoleic acid on production and energetic variables during the transition period. J. Dairy Sci. 90:293-305.

Overton, T. R., J. K. Drackley, C. J. Ottemann-Abbamonte, A. D. Beaulieu, L. S. Emmert, and J. H. Clark. 1999. Substrate utilization for hepatic gluconeogenesis is altered by increased glucose demand in ruminants. J. Anim. Sci. 77:1940-1951.

Renaville, R., A. Devolder, S. Massart, M. Sneyers, A. Burny, and D. Portetelle. 1993. Changes in the hypophysial-gonadal axis during the onset of puberty in young bulls. J. Reprod. Fertil. 99:443-449.

Santos, J. E. P., T. R. Bilby, W. W. Thatcher, C. R. Staples, and F. T. Silvestre. 2008. Long chain fatty acids of diet as factors influencing reproduction in cattle. Reprod. Domest. Anim. 43:23-30.

Shingfield, K. J., D. E. Beever, C. K. Reynolds, S. K. Gulati, D. J. Humphries, B. Lupoli, G. Hervas, and J. M. Griinari. 2004. Effect of rumen protected conjugated linoleic acid on energy metabolism of dairy cows during early to mid-lactation. J. Dairy Sci. 87(Suppl. 1):307. (Abstr.)

Tamminga, S., W. M. Vanstraalen, A. P. J. Subnel, R. G. M. Meijer, A. Steg, C. J. G. Wever, and M. C. Blok. 1994. The Dutch Protein Evaluation System-The DVE/OEB System. Livest. Prod. Sci. 40:139-155.

Van Es, A. J. H. 1978. Feed evaluation for ruminants. 1. Systems in use from May 1977 onwards in Netherlands. Livest. Prod. Sci. $5: 331-345$.

van Knegsel, A. T. M., H. van den Branda, J. Dijkstra, S. Tamminga, and B. Kemp. 2005. Effect of dietary energy source on energy balance, production, metabolic disorders and reproduction in lactating dairy cattle. Reprod. Nutr. Dev. 45:665-688.

Vlaeminck, B., C. Dufour, A. M. van Vuuren, A. R. J. Cabrita, R. J. Dewhurst, D. Demeyer, and V. Fievez. 2005. Use of odd and branched-chain fatty acids in rumen contents and milk as a potential microbial marker. J. Dairy Sci. 88:1031-1042.

Vlaeminck, B., M. Hostens, G. Opsomer, and V. Fievez. 2009. Delayed response of milk fatty acids to micro algae fed in early lactation. Pages 688-689 in Proc. Rumin. Physiol. Wageningen Academic Publishers, Clermont-Ferrand, France. 